\title{
PATHOGENESIS OF Eimeria colchici IN THE INTESTINE OF CHICKENS AND THE RELATED IMMUNE RESPONSE
}

\author{
A. LOÓSZOVÁ, V. REVAJOVÁ, M. LEVKUT, J. PISTL** \\ University of Veterinary Medicine, Department of Pathological Anatomy, *Department of Microbiology and \\ Immunology, Košice, Slovak Republic \\ Received October 24, 2000 \\ Accepted May 28, 2001 \\ Abstract \\ Loószová A., V. Revajová, M. Levkut, J. Pistl: Pathogenesis of Eimeria colchici in the \\ Intestine of Chickens and the Related Immune Response. Acta Vet. Brno 2001, 70: 191-196. \\ To study the immune response in poultry, a non-specific host for pheasant Eimeria colchici \\ coccidium, ten-day-old chickens were each orally inoculated with $10^{6}$ oocysts. For determination \\ and comparison of coccidia invasion and development, histological examinations in poultry and \\ pheasant chickens were made. In histological sections of four intestinal regions (duodenum, \\ jejunum, ileum and caeca), first generation schizonts were found in epithelial cells, 12, 36 and 60 \\ $\mathrm{h}$ post-infection (p.i.). Invasion of chicken intestine was non-specifically localized in the \\ duodenum and caecum. By $60 \mathrm{~h}$ p.i. the numbers of schizonts of $E$. colchici in chicken caecum were \\ significantly lower compared to the numbers of schizonts in pheasant caecum $(p<0.005)$. We \\ suppose that the size of the parasite was smaller in the fowl chickens as a result of a slower \\ development of the first generation schizonts of E. colchici. \\ In order to estimate the immunological response after administration, non-specific coccidia to \\ the chickens, subpopulations CD3+, CD4+, CD8+, and BU1b+ in the peripheral blood and spleen \\ were measured by flow cytometry. The indirect immunofluorescence method, mouse anti-chicken \\ monoclonal antibodies, and goat anti-mouse secondary antibody were used. A significant $(p<$ \\ 0.05 ) increase of leukocytes and CD4 positive T cells was observed at $60 \mathrm{~h}$ post infection in \\ chickens. We found that increase of CD4+ cells in a studied non-specific host infected with \\ pheasant coccidia is similar to increase of these cells in host specific coccidia infection. It indicates \\ participation of cellular immune response and one of the defence mechanisms during the invasion \\ and development of coccidia in a non-specific host.
}

Eimeria colchici, immunity, T-cell subsets, flow cytometry, intestine, experimental infection

Marked host and characteristic colonisation site specificity defines the development of Eimeria species in the digestive tract. It is rare for this protozoan parasite to occur naturally in more than one host (Aly 1993). Doran (1978), however, was able to produce an experimental, patent infection in Leghorn chickens, the chuckar partridge, ring-necked pheasant and bobwhite quail using a turkey coccidium, Eimeria dispersa. The prepatent period was $6 \mathrm{~h}$ shorter in the quail and partridge than in chicks and pheasants. Furthermore, the oocyst shedding in chicks and pheasants was much lower than in partridge and quail. The only similarity found among the four hosts was the size and the nature of the second and third generation schizonts. Nort on (1976) noted that E. colchici from a pheasant produced an infection in turkeys when a large number of oocyts was given to them.

Infection with Eimeria induces an immune reaction in the host, including both humoral and cell-mediated responses that lead to acquired protection. Although it is generally accepted that acquired immunity is parasite-host species-specific, Augustine and Danforth (1990) showed that chickens repeatedly inoculated with E. adenoeides develop a measure of immunity that protected them at least partially from a subsequent moderate challenge with E. tenella. Reciprocal infection studies, in which turkeys were immunised with E. tenella or $E$. acervulina failed to show protection against challenge with $E$. adenoeides (Augustine

Address for correspondence:

MVDr. V. Revajová, PhD

Dept. of Pathology

Komenského 73,041 81 Košice, Slovakia
Phone: +42195

Fax:

E-mail·revajova@uvm.sk

http://www. vfu.cz/acta-vet/actavet.htm 
and Danforth 1995). Mechanisms preventing the intracellular development of Eimeria in the non-specific hosts are not fully understood. One of the mechanisms likely to be involved is the immune system of the host. A dominant role of the cell-mediated immunity in the hostprotective response to Eimeria infection has been shown (Wakelin and Rose 1990; Rose and Hesketh 1982; Lillehoj and Trout 1993).

To study the infection of E. colchici in a non-specific host we investigated whether E. colchici could successfully colonize the intestine of the chicken host. To quantify the effects of a reciprocal "cross infection", we measured the elicited longitudinal changes in the blood and spleen lymphocyte subsets during infection.

\section{Materials and Methods}

Experimental design

Thirty-six coccidia-free (1-day-old) White Leghorn chicks were raised in standard poultry cages and given nonmedicated feed and water ad libitum. At $10 \mathrm{~d}$ of age, the birds were distributed randomly into treatment and control groups ( $\mathrm{n}=18$ in each). A pure culture of pheasant coccidium, Eimeria colchici, was obtained by isolation of a single oocyst on agar and infecting pheasant chicks and the oocysts collected from faeces were sporulated in $2 \%$ potassium dichromate (Goldová et al. 1998). Chicks of the treatment group were orally inoculated with $10^{6}$ oocysts per bird, while the control group was sham-infected with inoculum buffer only. Six chicks of both groups were killed at 12,36 and $60 \mathrm{~h}$ post infection and blood samples, and tissues were collected from spleen and intestine.

Thirty two-week-old coccidia-free pheasant chicks were infected with a pure suspension of sporulated $E$. colchici oocysts (5 000 oocysts/per chicks).

Histological examination

Intestinal samples were fixed in $10 \%$ neutral formalin and subjected to routine paraffin processing. From the sample blocks, $5 \mu \mathrm{m}$ thick histological sections were cut and stained with haematoxylin-eosin. The sizes and numbers of schizonts in epithelial cells of the small intestine were measured after calibration of eyepiece micrometer in 50 microscopic fields.

Counting of leukocytes and isolation of lymphocytes

Blood samples for flow cytometry examinations and counting of leukocytes were collected from all animals by cardiac puncture into EDTA containing tubes. Lymphocytes were separated by Ficoll-Hypaque gradient sedimentation (Boyum 1974). Leukocytes were counted by routine laboratory method using Fried - Lukáčová solution ( $475 \mu 1$ solution plus $25 \mu 1$ blood) (Fried and Jantošovič 1961).

The spleen cells for flow cytometry were harvested by teasing and passing the splenic tissue through a $70 \mu \mathrm{m}$ mesh screen (Heller 1987).

Antibodies

Primary antibodies: The primary mouse anti-chicken monoclonal antibodies (MoAbs) used are summarized in Table 1. They were obtained from Scandic (Czech Republic) and are produced by Veterinary Medical Research and Development Inc. (USA). The BU1b antibody was a generous gift of Prof. Heller.

Secondary antibody: FITC conjugated goat anti-mouse IgG (Dakopatts, Germany).

Table 1

Primary monoclonal antibodies

\begin{tabular}{|c|c|c|c|}
\hline Specificity & MoAbs & Isotype & Diluted \\
\hline CD3 & RTMCA1378 & mouse IgG1 & $1: 25$ \\
CD4 & SRTMCA1473 & mouse IgG1 & $1: 25$ \\
CD8 & SRTMCA1377 & mouse IgG1 & $1: 25$ \\
BU-1b & $8370-01$ & mouse IgG1 & $1: 25$ \\
\hline
\end{tabular}

Flow cytometry analysis

After the Ficoll-Hypaque separation, lymphocytes were twice washed with phosphate buffer saline (PBS) and once in a tissue cultured medium (TCM - RPMI 1640 supplemented by $2 \%$ of foetal calf serum). Fifty $\mu$ l of cellular suspension ( $1 \times 10^{6}$ lymphocytes in TCM) and $50 \mu \mathrm{l}$ of specific or control MoAbs were mixed and incubated at $4{ }^{\circ} \mathrm{C}$ for $30 \mathrm{~min}$. After incubation the cells were washed twice in the TCM, the resulting pellets were re-suspended and mixed with $25 \mu \mathrm{l}$ of secondary antibody and incubated in the dark as described above. After staining the cells were washed twice in the TCM and once in PBS, then fixed in $1 \%$ paraformaldehyde in PBS. Prepared samples 


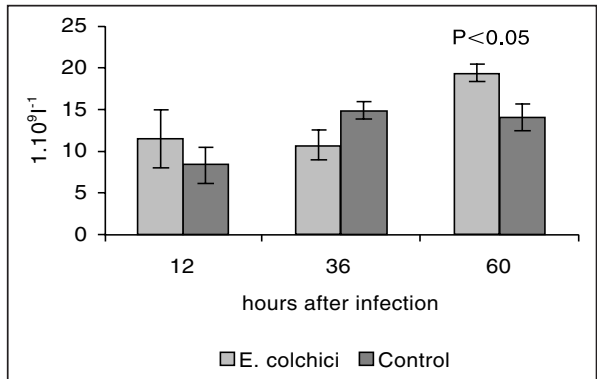

Fig. 1. Total number of leukocytes in the peripheral blood of domestic chicken after E. colchici infection

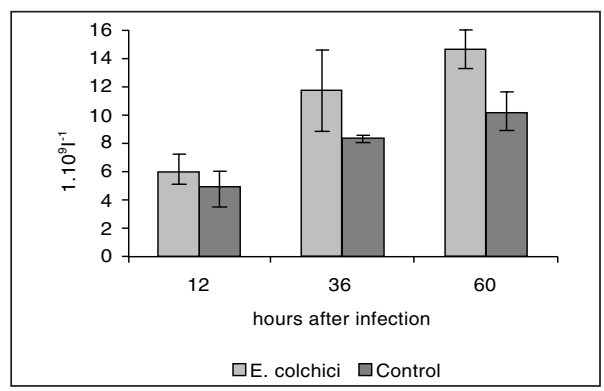

Fig. 2. Absolute number of lymphocytes in the peripheral blood of domestic chicken after $E$. colchici infection

were analysed on a Becton Dickinson FACScan flow cytometer (Germany). Data on 10000 cells were collected using the Becton Dickinson Cell Quest program. Absolute lymphocyte counts were computed as follows:

WBC count $\times \%$ of the relative lymphocytes $\times \%$ lymphocyte subpopulations

Statistical analysis

Results were evaluated by Student's $t$-test and expressed as mean $\pm \mathrm{SD}$. A confidence level of $p<0.05$ was considered significant.

\section{Results and Discussion}

Histological examinations of Leghorn chick intestines showed that the pheasant coccidium E. colchici invaded the epithelial cells of intestinal lamina propria mucosae of caecum and all parts of small intestine. Invasion of the intestine chickens was nonspecifically localized and was not equal to that observed in the intestinal cells of pheasant (Goldová et al. 1998). By sixty hours post infection (p.i.) the number of E. colchici schizonts in the chick caeca was very low $(1.4 \pm 1.2)$. It was significantly lower $(p<0.005)$ when compared to pheasant caecum infested with $E$. colchici $(1653.0 \pm 663.5)$ evaluated at similar time p.i. (Goldová et al. 2001).

Measurement and comparison of the schizont size revealed further differences between the specific and non-specific host, i.e. pheasants versus chicks. In the non-specific host, schizonts found in the duodenum, jejunum and ileum measured $5.7 \times 3.8 \mu \mathrm{m}$ at $12 \mathrm{~h}$ p.i. and $9.5 \times 7.6 \mu \mathrm{m}$ at $36 \mathrm{~h}$ p.i.

A much lower number of schizonts were found $60 \mathrm{~h}$ p.i. These were identical in size (5.7 $\times 3.8 \mu \mathrm{m}$ ) to those found in the $12 \mathrm{~h}$ p.i. localized mainly in the duodenum. In contrast, examination of the pheasant host, infected with its host-specific parasite species, E. colchici, showed a number of marked differences. Many of them were noted in the classical works on Eimeria by Pellérdy (1974) and Norton (1976). They found the first generation schizonts in the lower part of the small intestine having a significantly larger dimension (18

Table 2

CD3 and CD8 positive T cells in the peripheral blood (absolute numbers; $1.10^{9} \cdot \mathrm{l}^{-1}-\mathrm{G} \cdot \mathrm{l}^{-1}$ ) and in the spleen (percentage) in the chickens after $E$. colchici infection (Means $\pm \mathrm{SD}$ )

\begin{tabular}{|c|c|c|c|c|c|c|c|c|}
\hline \multirow{2}{*}{} & \multicolumn{2}{|c|}{ CD3 } & \multicolumn{2}{c|}{ CD8 } & \multicolumn{2}{c|}{ CD3 } & \multicolumn{2}{c|}{ CD8 } \\
\cline { 2 - 8 } & \multicolumn{2}{|c|}{ blood $\left(\mathrm{G} \cdot \mathrm{l}^{-1}\right)$} & \multicolumn{2}{c|}{ Blood $\left(\mathrm{G} \cdot \mathrm{1}^{-1}\right)$} & \multicolumn{2}{c|}{ Spleen $(\%)$} & \multicolumn{2}{c|}{ Spleen $(\%)$} \\
\hline h p.i. & Control & E. colchici & Control & E. colchici & Control & E. colchici & Control & E. colchici \\
\hline 12 & $0.89 \pm 0.5$ & $2.21 \pm 0.9$ & $0.45 \pm 0.4$ & $0.60 \pm 0.4$ & $33 \pm 5$ & $43 \pm 11$ & $39 \pm 6$ & $30 \pm 9$ \\
36 & $1.87 \pm 0.5$ & $1.29 \pm 0.1$ & $1.20 \pm 0.6$ & $1.45 \pm 0.3$ & $43 \pm 10$ & $36 \pm 17$ & $48 \pm 2$ & $43 \pm 3$ \\
60 & $1.23 \pm 0.7$ & $2.11 \pm 0.5$ & $0.84 \pm 0.6$ & $1.22 \pm 0.7$ & $52 \pm 11$ & $59 \pm 18$ & $48 \pm 2$ & $47 \pm 11$ \\
\hline
\end{tabular}




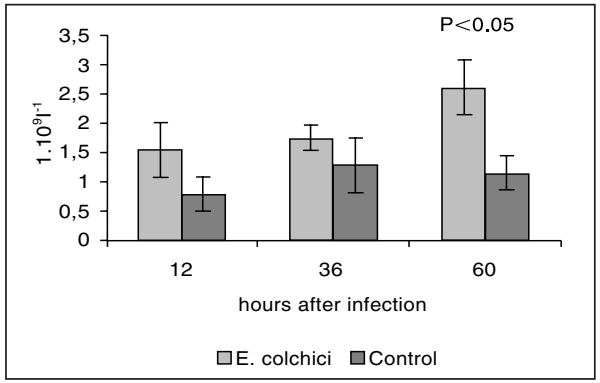

Fig. 3. Absolute number of CD4 positive cells in the peripheral blood of domestic chicken after E. colchici infection

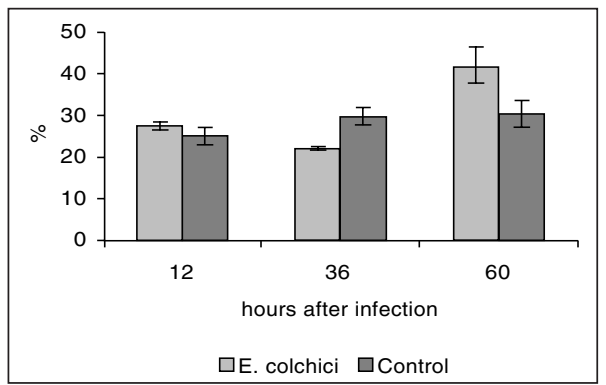

Fig. 4. Relative percentage of CD4 positive cells in the spleen of domestic chicken after E. colchici infection

$\times 13 \mu \mathrm{m})$. Goldová et al. (1993) described the E. colchici localisation in the caecal crypts, where they reached $18.7 \times 15.1 \mu \mathrm{m}$. The second generation schizonts appeared as colonies in the lamina propria of the caecal mucosa and measured $28 \times 21 \mu \mathrm{m}$ (Pellérdy 1974; Norton 1976; Goldová et al. 1993).

We are not aware of reports dealing with the developmental stages of E. colchici that show diminished ability to colonize, develop and thrive in non-specific or foreign host birds. The diminished ability of a turkey-specific Eimeria spp. to colonize the chicken digestive tract was shown by Augustine et al. (1991). In an experiment using parasite-specific monoclonal antibodies, they showed that the sporozoites of the turkey coccidia survived within the chicken intestinal cells for up to 3 days but failed to develop.

Evaluation of the total number of the peripheral blood leukocytes (Fig. 1) and lymphocytes (Fig. 2) showed significant increase of leukocytes $(p<0.05$ at 60 h p.i.) and mild increase of lymphocytes in the infected group as compared to the control. Absolute number of CD3 (Table 2), CD4+ (Fig. 3 and 4), CD8+ (Table 2), BU1b+ (Fig. 5 and 6) cells and ratio of CD4/CD8 (Table 3) cells in both, the peripheral blood and spleen reflected a statistically significant increase of CD4+ cells at $60 \mathrm{~h}$ p.i. in the peripheral blood.

The results demonstrated that during sporozoite invasion of a non-specific host, the antigen-specific T cells were activated. An increased number of CD4 should have contributed cytokine support for an antibody response and possible for phagocytic killing of E. colchici. CD4+ T cells are also important in controlling primary infection with $E$. tenella in natural host-chicken (Trout and Lillehoj 1996). T lymphocytes have a direct effect on preventing the development of Eimeria sporozoites once they invade the intestinal mucosa of a nonspecific host. On the other hand, suppression of T lymphocyte activity in a non-specific host

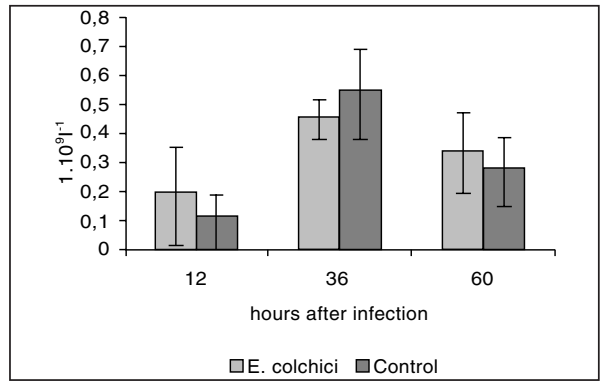

Fig. 5. Absolute number of Bulb positive cells in the peripheral blood of domestic chicken after E. colchici infection

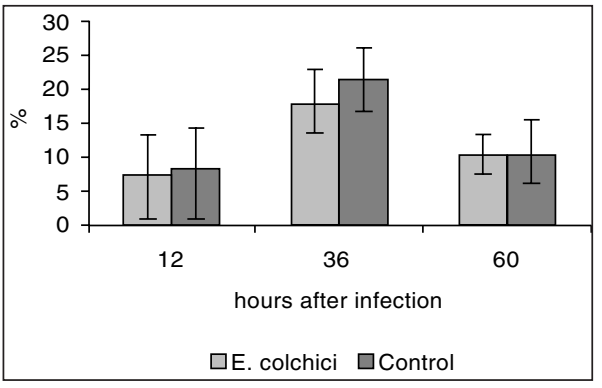

Fig. 6. Relative percentage of Bulb positive cells in the spleen of domestic chicken after E. colchici infection 
Table 3

$\mathrm{CD} 4 / \mathrm{CD} 8$ ratio in the peripheral blood and in the spleen after $E$. colchici infection (Means $\pm \mathrm{SD}$ )

\begin{tabular}{|c|c|c|c|c|}
\hline \multirow{2}{*}{ h p.i. } & \multicolumn{2}{|c|}{ Peripheral blood } & \multicolumn{2}{c|}{ Spleen } \\
\cline { 2 - 5 } & Control & E. colchici & Control & E. colchici \\
\hline $12 \mathrm{~h}$ & $2.00 \pm 0.63$ & $2.98 \pm 0.88$ & $0.63 \pm 0.04$ & $0.96 \pm 0.30$ \\
$60 \mathrm{~h}$ & $1.11 \pm 0.64$ & $1.21 \pm 0.33$ & $0.58 \pm 0.08$ & $0.50 \pm 0.02$ \\
$60 \mathrm{~h}$ & $1.18 \pm 0.15$ & $2.79 \pm 1.60$ & $0.63 \pm 0.08$ & $0.92 \pm 0.30$ \\
\hline
\end{tabular}

early during an infection with a heterologous species of Eimeria permitted the complete intracellular development of the parasite (Kogut and Eirmann 1991).

In conclusion, infection of chicks with pheasant host-specific coccidia resulted in dispersed, impotent invasion of the caeca and small intestine of the chicks. Schizonts in the intestinal mucosa failed to develop and were also significantly smaller than those in natural hosts. These findings taken together support the notion that the measured changes in WBC's in general and CD4+ cells changes in particular indicate participation in the defence of the intestinal mucosa during the invasion and development of coccidia in a non-specific host.

\section{Patogenéza Eimeria colchici v čreve kurčiat a imunitná odpoved'}

Za účelom štúdia imunitnej odpovede hydiny, ktorá je nešpecifickým hostitelom pre bažantie kokcídie $E$. colchici, kurčatá vo veku 10 dní boli infikované per os oocystami bažantích kokcídií (Eimeria colchici). Kvôli stanoveniu a porovnaniu invázie a vývoja kokcídií bolo vykonané histologické vyšetrenie kurčiat a bažantov. Histologické rezy čreva (duodenum, jejunum, ileum a cecum) 12, 36 a 60 h po infekcii, v epiteliálnych bunkách sliznice demonštrovali vývoj po prvú generáciu schizontov. Invázia čreva kurčiat bola nešpecificky lokalizovaná v duodéne a céku. Šesṫdesiat hodín po infekcii počty schizontov E. colchici v céku kurčiat boli signifikantne nižšie v porovnaní s počtami schizontov $E$. colchici v céku bažantov $(p<0.005)$. Predpokladáme, že velkost parazita u kurčiat bola menšia ako u bažantov z dôvodu spomaleného vývoja prvej generácie schizontov E. colchici.

Imunologickú odpoved u kurčiat po aplikácií bažantích kokcídií sme sledovali prietokovou cytometriou $\mathrm{v}$ periférnej krvi a slezine. Využili sme metódu nepriamej imunofluorescencie s použitím primárnych myšacích antikuracích monoklónových protilátok (CD3, CD4, CD8 a BU1b) a sekundárnej kozej antimyšacej protilátky konjugovanej s FITC. Šesṫdesiat hodín po infekcii kurčiat sa v periférnej krvi pozorovalo signifikantné $(p<0.05)$ zvýšenie leukocytov a CD4 pozitívnych buniek. Zistili sme, že podobne ako po infekcii špecifickými kuracími kokcídiami, došlo k zvýšeniu CD4 pozitívnych buniek aj u nešpecifického hostitela infikovaného bažantou kokcídiou. To poukazuje na účast bunkovej imunitnej odpovede a jeden z možných obranných mechanizmov v priebehu invázie a vývoja bažantích kokcídií u nešpecifického hostitela.

\section{Acknowledgements}

This study was partly supported by Science Grant Agency (VEGA) grant 1/7018/20.

\section{References}

ALY, M. M. 1993: Development of Eimeria stiedae in a non-specific host. J. Egypt. Soc. Parasitol. 23: 95-99 AUGUSTINE, P. C., DANFORTH, H. D. 1990: Avian Eimeria: invasion in foreign host birds and generation of partial immunity against coccidiosis. Avian Dis. 34: 196-220

AUGUSTINE, P. C., DANFORTH, H. D., BARTA, J. L. 1991: Development of protective immunity against 
Eimeria tenella and E. acervulina in White Leghorn chickens inoculated repeatedly with high doses of turkey coccidia. Avian Dis. 35: 535-541

AUGUSTINE, P. C., DANFORTH, H. D. 1995: Eimeria tenella and E. acervulina: Differences in ability to elicit cross-species protection as compared with the turkey coccidium, E. adenoeides. Avian Dis. 39: 709-717

BOYUM, M. A. 1974: Separation of blood leucocytes, granulocytes and lymphocytes. Tissue Antigens 4: 269-274

DORAN, D. J. 1978: The life cycle of Eimeria dispersa Tyzzer 1929 from the turkey in gallinaceous birds. J. Parasitol. 64: 882-885

FRIED, K., JANTOŠOVIČ, J. 1961: Blood sampling by cardiac punction. (In Slovak). Vet. čas. 10: 383-391

GOLDOVÁ, M., CSIZSMÁROVÁ, G., LETKOVÁ, V., KOČIŠ, J., KOLODZIEYSKI, L. 1993: The course of the endogenous phase of Eimeria colchici and Eimeria duodenalis development in pheasants (Phasianus colchicus) (In Slovak). Veterinářství 43: 286-287

GOLDOVÁ, M., CSIZSMÁROVÁ, G., LETKOVÁ, V. 1998: Course of the endogenous developmental phase of selected Eimeria species in pheasants. Vet. Parasitol. 77: 289-295

GOLDOVÁ, M., REVAJOVÁ, V., PISTL, J., LEVKUT, M., WAGSHAL, E., CSIZSMÁROVÁ, G., LOÓSZOVÁ, A. 2001: Eimeria colchici and immunocompetent cells in specific and non-specific hosts. Acta Parasitol. 46: 39-44

HELLER, E. D., SCHAT, K. A. 1987: Enhancement of natural killer cell activity by Marek's disease vaccines. Avian Pathol. 16: 51

KOGUT, M. H., EIRMANN, L. 1991: The effect of cyclosporin A on the development of Eimeria in non-specific hosts. Int. J. Parasitol. 21: 979-983

LILLEHOJ, H. S., TROUT, J. M. 1993: Coccidia: A review of recent advances on immunity and vaccine development. Avian Pathol. 22: 3-31

NORTON, C. C. 1993: Eimeria colchici sp. n. (Protozoa, Eimeriidae) the cause of caecal coccidiosis in Engl. cov. pheasants. J. Protozool. 14: 772

NORTON, C. C. 1976: Coccidia of the pheasant. Folia Vet. Latin 6: 218-238

PELLÉRDY, L. P. 1974: Coccidia and Coccidiosis. 2nd Ed. Parey Verlag, Berlin, 959 p.

ROSE, M. E., HESKETH, P. 1982: Immunity to coccidia in chickens: adoptive transfer with peripheral blood lymphocytes and spleen cells. Parasite Immunol. 4: 171-185

TROUTH, J. M., LILLEHOJ, H. S. 1996: T lymphocyte role during Eimeria acervulina and Eimeria tenella infection. Vet. Immunol. Immunopathol. 53: 163-172

WAKELIN, D., ROSE, M. E. 1990: Immunity to coccidiosis. In: LONG, P. L.: Coccidiosis of Man and Domestic Animals. CRC Press, Boca Raton, Florida, pp. 282-306 